\title{
ZANTEDESCHIA AETHIOPICA (L.) SPRENG.: A REVIEW OF ITS MEDICINAL USES, PHYTOCHEMISTRY, AND BIOLOGICAL ACTIVITIES
}

\author{
ALFRED MAROYI* \\ Department of Botany, Medicinal Plants and Economic Development Research Centre, University of Fort Hare, Private Bag X1314, \\ Alice 5700, South Africa. Email: amaroyi@ufh.ac.za
}

Received: 29 March 2019, Revised and Accepted: 24 June 2019

\begin{abstract}
Zantedeschia aethiopica is an evergreen monocotyledonous herb widely used as herbal medicine and ornamental plant. The current study is aimed at reviewing the medicinal uses, phytochemistry, and biological activities of Z. aethiopica. Information on biological activities, medicinal uses, and phytochemistry of Z. aethiopica was gathered from several internet sources which included Scopus, Google Scholar, Elsevier, Science Direct, Web of Science, PubMed, SciFinder, and BMC. Additional information on these aspects was sourced from pre-electronic sources such as journal articles, scientific reports, theses, books, and book chapters obtained from the University Library. The current study revealed that Z. aethiopica is mainly used as herbal medicine for boils, burns, gout, inflammation, insect bites, rheumatism, sores, and wounds. Phytochemical and pharmacological studies showed that Z. aethiopica extracts and compounds isolated from the species have antibacterial, antifungal, antioxidant, antihistaminic, antialgal, antithrombotic, and anticoagulant activities. This research showed that Z. aethiopica is an integral part of the traditional pharmacopeia in several countries where the species is indigenous or naturalized, but there is the lack of alignment between the known medicinal applications, phytochemistry, and biological activities of the species. Therefore, future research should focus on evaluating the chemical and pharmacological properties of Z. aethiopica extracts and compounds associated with the species.
\end{abstract}

Keywords: Araceae, Ethnopharmacology, Herbal medicine, Southern Africa, Zantedeschia aethiopica.

(C) 2019 The Authors. Published by Innovare Academic Sciences Pvt Ltd. This is an open access article under the CC BY license (http://creativecommons. org/licenses/by/4. 0/) DOI: http://dx.doi.org/10.22159/ajpcr.2019.v12i8.34353

\section{INTRODUCTION}

Zantedeschia aethiopica (L.) Spreng. is an evergreen herb which is a member of a monocotyledonous flowering plants Araceae family also known as arum lily family. Z. aethiopica is an important food, medicinal and ornamental plant in Africa, Asia, Australia, Europe, and the United States of America, and recently playing an important role in cleaning up contaminated soils and water [1-6]. Research by Halligan et al. [7] and Wei etal. [8] showed that Z. aethiopica is sold worldwide as an ornamental plant and the species is cultivated commercially as an ornamental flower [9-12] with the foliage and flowers employed principally for coronas and other funeral decorations on altars and shrines and as cut flowers. In South Africa, Z. aethiopica is one of the valuable medicinal plant species in the country and the species is included in the book "medicinal plants of South Africa," a photographic guide to the most commonly used herbal medicines in the country, including its botany, major medicinal applications active phytochemical compounds [13]. Similarly, research by Reinsten et al. [12] showed that Z. aethiopica has commercial potential for the cut flower trade as potted flowers and foliages in South Africa. The tuberous rootstock of $Z$. aethiopica is said to have been a food source in early days in South Africa after extensive boiling to counteract the burning effect of the raphide crystals $[14,15]$. The leaves and stems of Z. aethiopica are cooked as potherbs and leafy vegetables in Lesotho, Zimbabwe, the Eastern Cape, Free State, and KwaZulu-Natal Provinces in South Africa [14-26]. However, the leaves of Z. aethiopica are among the top 10 culprits of plant species responsible for about $6.5 \%$ of all poisoning cases (about 500 cases and inquiries per year) in the Johannesburg municipal area in South Africa [27]. Although Z. aethiopica is not indigenous to New Zealand, the species is the second most common poisonous plant in the country [28]. Research by Botha and Penrith [29], Wink and Van Wyk [30], and Ndhlala et al. [31] showed that the cardiac glycosides which have been identified from the species and known to induce paralysis on the central nervous system are probably responsible for the toxic properties of the species. However, Van Wyk et al. [27] argued that Z. aethiopica is not toxic, but the oxalate crystals associated with the species may cause distress if fresh leaves are eaten. Similarly, Van Wyk et al. [13] argued that Z. aethiopica should not be eaten fresh as the needle-shaped calcium oxalate crystals cause mechanical irritation of the mucous membranes, causing swelling of the tongue and throat, salivation, nausea, vomiting, and diarrhea. However, $Z$. aethiopica is a valuable medicinal plant, as its rhizomes and roots are sold as herbal medicines in the Limpopo Province in South Africa $[32,33]$ and Brazil $[34,35]$. It is within this context that the current study was undertaken aimed at providing a comprehensive review of the medicinal value, phytochemistry and biological activities of the compounds isolated from the species, including Z. aethiopica crude extracts.

\section{BOTANICAL DESCRIPTION OF Z. AETHIOPICA}

Z. aethiopica is a perennial, robust, evergreen or deciduous, erect and clump-forming herbaceous plant with a thick rhizome and white fleshy roots. Z. aethiopica grows up to $150 \mathrm{~cm}$ in height with large, fleshy leaves developing from the tuberous rhizome [36-39]. The leaves are dark glossy green in color, lack a persistent basal meristem, are large, leathery and hairless, ovate in shape with parallel-pinnate veins, characterized by a thick and spongy leaf stalk. The minute yellow or cream-colored flowers are borne in a dense group on a finger-like column (so-called spadix), surrounded by a large, white, leaf-like structure (the spathe) [13]. A dense mass of small, fleshy, soft, berrylike yellow fruits develops at the base of the spadix. Z. aethiopica is native to Lesotho, South Africa, and Swaziland [14,17,36,37,40-42]. In Southern Africa, Z. aethiopica has been recorded in sandy or rocky places, along the coast, mountain grasslands, usually seasonally damp depressions and permanent springs at an altitude ranging from $20 \mathrm{~m}$ to $2250 \mathrm{~m}$ above sea level $[38,39,41]$. Z. aethiopica is also naturalized in Australia, Brazil, Hawaii, India, Italy, Kenya, Malawi, New Zealand, Philippines, Portugal, Réunion, South America, Spain, Tanzania, Tunisia, the United Kingdom, and Zambia [42-50].

The genus Zantedeschia Spreng. consists of seven species, namely, Z. aethiopica (L.) Spreng., Zantedeschia albomaculata (Hook.) Baill., 
Zantedeschia rehmannii Engl., Zantedeschia pentlandii (Watson) Wittm., Zantedeschia elliottiana (Watson) Engl., Zantedeschia jucunda Letty, and Zantedeschia odorata P.L.Perry. [37]. Z. aethiopica is named after Prof Giovanni Zantedeschi (1773-1846), an Italian botanist and physician $[14,51,52]$. The species name "aethiopica" is indirectly related to Ethiopia as in classical times, the name was used in reference to "south of the known world," that is, South of Libya and Egypt, now known as Southern Africa [14,52]. Z. aethiopica is commonly referred to as "arum lily," "calla lily," "cape white alum lily," "Egyptian lily," "florist's calla," and "garden calla" in English $[13,14,23]$. The synonyms associated with Z. aethiopica include Calla aethiopica L., Richardia aethiopica (L.) Spreng., Richardia Africana Kunth, and Z. aethiopica (L.) Spreng. var. minor Engl. [37,40-42,48].

\section{MEDICINAL USES OF Z. AETHIOPICA}

The leaves, rhizomes, roots, stems, and the whole plant parts of Z. aethiopica are used as herbal medicines against 33 human diseases in tropical Africa, Asia, and North America (Table 1). Z. aethiopica is mainly used as herbal medicine for boils, burns, gout, inflammation, insect bites, rheumatism, sores, and wounds (Fig. 1). Other medicinal applications recorded in at least two literature sources include asthma, colds, flu, headache, heartburn, infections, infertility, respiratory problems, sore throat, and as a protective charm (Table 1). Such wide usage of $Z$. aethiopica as herbal medicine implies that the species is a valuable source of therapeutic agents required for plant-derived natural products or their derivatives.

\section{CHEMICAL AND PHYTOCHEMISTRY OF Z. AETHIOPICA}

Carneiro et al. [89] and Pelo [90] quantified mineral elements in flower stalks, leaves, rhizomes, and roots of Z. aethiopica including heavy metals such as cadmium, copper, chromium, iron, lead, manganese, and mercury (Table 2). The concentrations of the heavy metals in Z. aethiopica are below the permissible FAO or the WHO limits set by Codex Alimentarius Commission [91], and therefore, the use of the species as food or its extracts as herbal medicines may not result in heavy metal toxicity. Medicinal plants growing in different geographical areas usually accumulate different levels of heavy metals [92,93]. Phytochemical compounds that have been identified from flowers, fruits, leaves, and regreened sphates, and stems of Z. aethiopica include alkaloids, anthraquinones, cardiac glycosides, flavonoids, glucose, saponins, soluble starch, steroids, sucrose, tannins, and terpenoids [90,94-96]. Other phytochemical compounds that have been

Table 1: Medicinal applications of Zantedeschia aethiopica

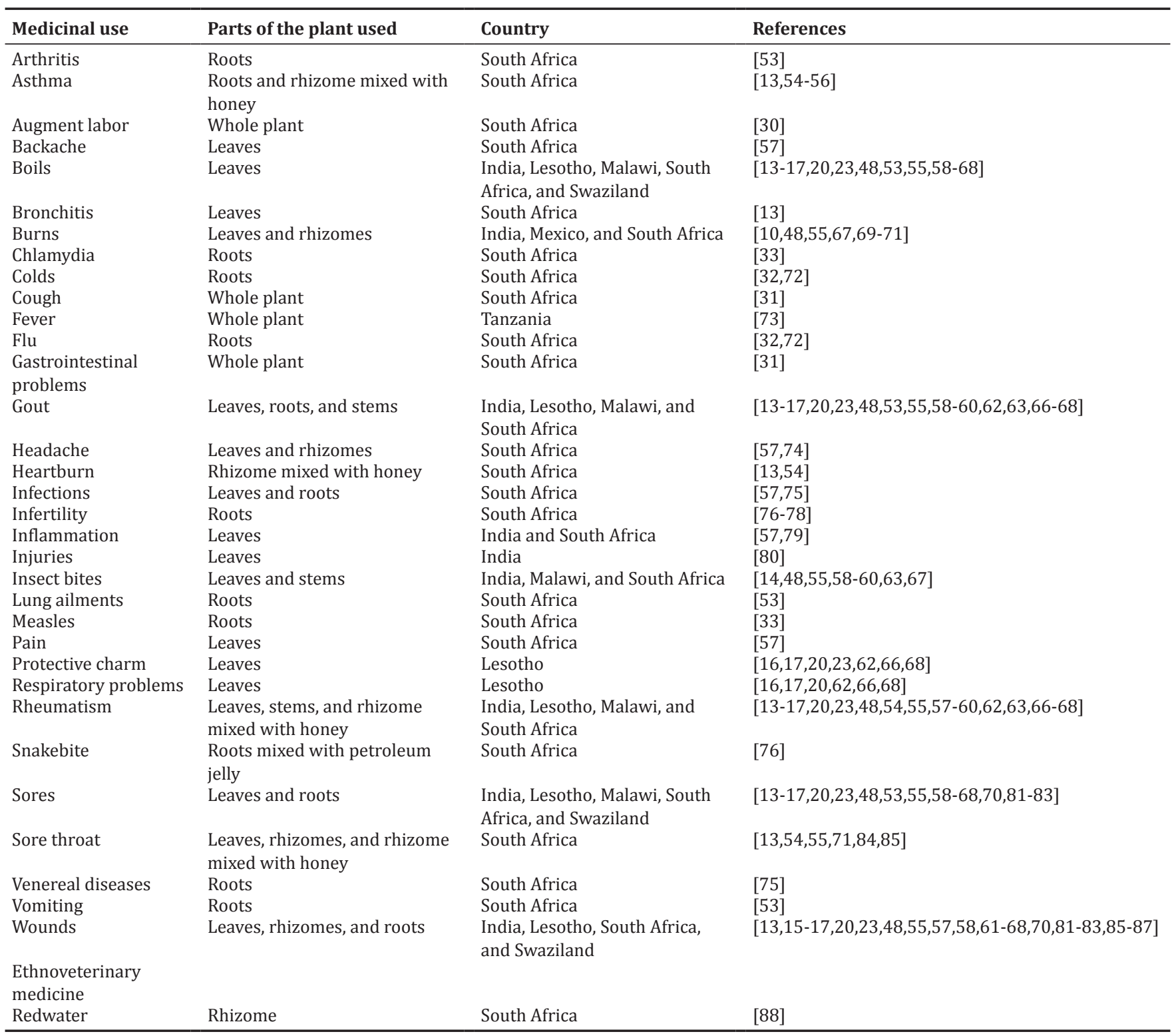


identified from fruits, leaves, and regreened sphates of Z aethiopica include cytokinin, cycloartane triterpenes, fatty acids, galactolipids, galactosyldiacylglycerols, phytosterols, and steroids [90,95,97-101] (Table 3).

\section{BIOLOGICAL ACTIVITIES OF Z. AETHIOPICA}

The following biological activities have been reported from the leaf and root extracts and compounds isolated from Z. aethiopica: Antibacterial [54,63-65,90,96], antifungal [54,63-65,102,103], antithrombotic and anticoagulant [104], antioxidant [105], antihistaminic [54], and antialgal [95] activities.

\section{Antibacterial activities}

Nielsen et al. [63] evaluated antibacterial activities of methanol leaf and stem extracts of Z. aethiopica against Citrobacter, Staphylococcus aureus, Escherichia coli, Klebsiella pneumoniae, Pseudomonas aeruginosa, and Mycobacteria smegmatis using the microbroth dilution method with gentamicin and ciprofloxacin as positive controls. The extracts exhibited weak activities with minimum inhibitory concentration (MIC) values ranging from $625 \mu \mathrm{g} / \mathrm{ml}$ to $>2500 \mu \mathrm{g} / \mathrm{ml}$ which were much higher than MIC values of $0.3 \mu \mathrm{g} / \mathrm{ml}$ to $19.5 \mu \mathrm{g} / \mathrm{ml}$ exhibited by the controls [63]. Pratush et al. [96] evaluated antibacterial activities of ethanolic and aqueous extracts of the rhizomes of $Z$. aethiopica against $S$. aureus, P. aeruginosa, E. coli, Bacillus subtilis, K. pneumonia, Serratia marcescens, Shigella spp., and Salmonella typhi using disk diffusion method. The extracts exhibited activities against all the tested

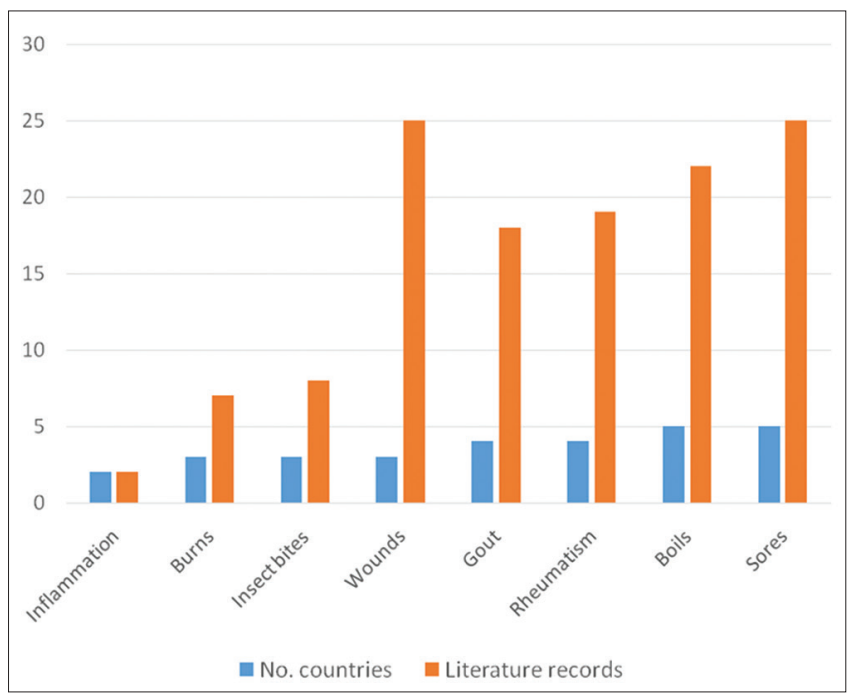

Fig. 1: Medicinal applications of Zantedeschia aethiopica pathogens with the exception of $S$. marcescens and Shigella spp. with zone of inhibition ranging from $2.3 \mathrm{~mm}$ to $4.1 \mathrm{~mm}$ [96]. De Almeida et al. [106] evaluated antibacterial activities of floral protein extracts of Z. aethiopica against E. coli, K. pneumoniae, Proteus mirabilis, Salmonella typhimurium, Shigella flexneri, Streptococcus pyogenes, and $S$. aureus using microdilution method. E. coli was the only pathogen that inhibited the extract by $96.3 \%$ [106]. Mabona [64] and Mabona et al. [65] evaluated the antibacterial activities of aqueous and dichloromethane:methanol (1:1) leaf extracts of Z. aethiopica using the microtiter plate assay against dermatologically relevant pathogens such as Brevibacillus agri, Propionibacterium acnes, P. aeruginosa, S. aureus, and Staphylococcus epidermidis with ciprofloxacin as a positive control. The extracts exhibited activities with MIC values ranging from $0.5 \mathrm{mg} / \mathrm{ml}$ to $>16.00 \mathrm{mg} / \mathrm{ml}$ [64,65]. Motlhatlego [54] evaluated the antibacterial activities of aqueous, dichloromethane, $80 \%$ ethanol and petroleum ether leaf, rhizome, root, and stem extracts of $Z$. aethiopica against $S$. pyogenes, $K$. pneumoniae, and S. aureus using microdilution technique with neomycin as a positive control and Haemophilus parainfluenzae using disk diffusion method with ampicillin and penicillin as positive controls. The extracts exhibited activities with MIC values ranging from $0.8 \mathrm{mg} / \mathrm{ml}$ to $>12.5 \mathrm{mg} / \mathrm{ml}$ and zone of inhibition of $21.1 \mathrm{~mm}$ which was comparable to $18.9 \mathrm{~mm}$ to $21.6 \mathrm{~mm}$ exhibited by ampicillin and penicillin [54]. Pelo [90] evaluated antibacterial activities of chloroform: methanol, ethyl acetate, hexane, and waterleaf extracts of $Z$. aethiopica against Bacillus cereus, B. subtilis, Enterobacter cloacae, Enterobacter aerogenes, Enterococcus faecalis, K. pneumoniae, M. smegmatis, P. mirabilis, Proteus vulgaris, $P$. aeruginosa, and $S$. aureus using disk diffusion method and microdilution method. Only chloroform:methanol extract exhibited activities against M. smegmatis with zone of inhibition ranging from $7 \mathrm{~mm}$ to $11 \mathrm{~mm}$. The MIC susceptible assay revealed that organic extracts were active against the tested pathogens with MIC values ranging from $0.3 \mathrm{mg} / \mathrm{mL}$ to $8.0 \mathrm{mg} / \mathrm{mL}$ [90].

\section{Antifungal activities}

Motsei [102] and Motsei et al. [103] evaluated antifungal activities of aqueous, ethanol, ethyl acetate, and hexane leaf extracts of $Z$. aethiopica against Candida albicans standard strain ATCC 10231 and two clinical isolates from a 5-month-old baby and an adult using the broth microdilution method with amphotericin B as a positive control. The extracts exhibited weak activities with MIC values ranging from $>8.4 \mathrm{mg} / \mathrm{ml}$ to $>25.0 \mathrm{mg} / \mathrm{ml}[102,103]$. Nielsen et al. [63] evaluated antifungal activities of methanol leaf and stem extracts of $Z$. aethiopica against $C$. albicans and Microsporum audouinii using the microbroth dilution method with nystatin as a positive control. The extracts exhibited moderate activities with MIC value of $312.5 \mu \mathrm{g} / \mathrm{ml}$ against both fungi in comparison to MIC value of $19.5 \mu \mathrm{g} / \mathrm{ml}$ exhibited by the control [63]. Mabona [64] and Mabona and Van Vuuren [65] evaluated the antifungal activities of aqueous and dichloromethane:methanol

Table 2: Mineral element composition of Zantedeschia aethiopica

\begin{tabular}{|c|c|c|c|c|}
\hline Element & Value & FAO/WHO permissible limit & Plant part & References \\
\hline Cadmium (mg/kg) & 0.002 & 0.02 & Leaves & [90] \\
\hline Calcium $(\mathrm{mg} / \mathrm{kg})$ & $1.2-7.7$ & - & Flower stalks, leaves, rhizomes, and roots & {$[89,90]$} \\
\hline Chromium (mg/kg) & 0.003 & 1.3 & Leaves & {$[90]$} \\
\hline Copper $(\mathrm{mg} / \mathrm{kg})$ & $<0.001$ & 10.0 & Leaves & [90] \\
\hline Iron $(\mathrm{mg} / \mathrm{kg})$ & 0.04 & 20.0 & Leaves & [90] \\
\hline Lead $(\mathrm{mg} / \mathrm{kg})$ & 0.03 & 2.0 & Leaves & [90] \\
\hline Magnesium (mg/kg) & 2.8 & - & Flower stalks, leaves, rhizomes, and roots & [89] \\
\hline Mercury $(\mathrm{mg} / \mathrm{kg})$ & 0.006 & 0.6 & Leaves & [90] \\
\hline Nitrogen $(\mathrm{mg} / \mathrm{kg})$ & 25.9 & - & Flower stalks, leaves, rhizomes, and roots & [89] \\
\hline Phosphorus (mg/kg) & 6.2 & - & Flower stalks, leaves, rhizomes, and roots & [89] \\
\hline Potassium (mg/kg) & $0.09-0.37$ & - & Flower stalks, leaves, rhizomes, and roots & {$[89,90]$} \\
\hline Sodium $(\mathrm{mg} / \mathrm{kg})$ & 0.005 & - & Leaves & {$[90]$} \\
\hline Strontium (mg/kg) & 0.003 & - & Leaves & [90] \\
\hline Sulfur $(\mathrm{mg} / \mathrm{kg})$ & 0.07 & - & Flower stalks, leaves, rhizomes, and roots & [89] \\
\hline Zinc (mg/kg) & $<0.001$ & 50.0 & Leaves & [90] \\
\hline
\end{tabular}


(1:1) leaf extracts of $Z$. aethiopica using the microtiter assay against dermatologically relevant pathogens such as $C$. albicans, Microsporum canis, and Trichophyton mentagrophytes with amphotericin B as a positive control. The extracts exhibited activities with MIC values ranging from $1.0 \mathrm{mg} / \mathrm{ml}$ to $4.0 \mathrm{mg} / \mathrm{ml}$ [64,65]. Motlhatlego [54] evaluated the antifungal activities of aqueous, dichloromethane, $80 \%$ ethanol and petroleum ether leaf, rhizome, root, and stem extracts of $Z$. aethiopica against $C$. albicans using microdilution technique with

Table 3: Phytochemical composition of Zantedeschia aethiopica

\begin{tabular}{|c|c|c|c|}
\hline Phytochemical & Value & Plant parts & References \\
\hline Galactolipids & - & Leaves and regreened sphates & [99] \\
\hline Galactosyldiacylglycerols & - & Leaves and regreened sphates & [99] \\
\hline$\alpha$-linolenic acid & - & Leaves and regreened sphates & {$[95,99]$} \\
\hline 13-hydroxy- $\alpha$-linolenic acid & - & Leaves & [95] \\
\hline Linoleic acid & - & Leaves and regreened sphates & {$[95,99]$} \\
\hline 9-hydroxy-linoleic acid & - & Leaves & [95] \\
\hline 12-hydroxy-linoleic acid & - & Leaves & [95] \\
\hline Oleic acid (\%) & 14.1 & Leaves and regreened sphates & {$[90,99]$} \\
\hline Palmitic acid & - & Leaves and regreened sphates & [99] \\
\hline Palmitoleic acid & - & Leaves and regreened sphates & [99] \\
\hline Stearic acid & - & Leaves and regreened sphates & [99] \\
\hline$\Delta^{3}$-trans-hexadecenoic acid & - & Leaves and regreened sphates & {$[99,100]$} \\
\hline Cycloartenol & - & Leaves & [95] \\
\hline 24-methylene-cycloartanol & - & Leaves & [95] \\
\hline (24R)-24-Ethyl-cholest-5-en-3 $\beta$-ol (\%) & 93.1 & Leaves & [95] \\
\hline (24S)-24-Ethyl-cholest-5,22-dien-3 $\beta$-ol (\%) & 1.1 & Leaves & [95] \\
\hline 24-Methylene-cholest-7-en-3 $\beta$-ol (\%) & 0.2 & Leaves & [95] \\
\hline $4 \alpha$-Methyl-24-methylene-cholest-7-en-3 $\beta$-ol (\%) & 0.3 & Leaves & [95] \\
\hline (24R)-24-Ethyl-cholest-4-en-6 $\beta$-ol-3-one $(\%)$ & 0.7 & Leaves & [95] \\
\hline (24R)-24-Methyl-5 $\alpha, 8$-epidioxy-cholest-6,22-dien-3 $\beta$-ol (\%) & 1.4 & Leaves & [95] \\
\hline (24R)-24-Ethyl-cholest-5-en-3 $\beta, 7 \beta$-diol (\%) & 0.7 & Leaves & [95] \\
\hline (24R)-24-Ethyl-cholest-5-en-3 $\beta, 7 \alpha$-diol (\%) & 0.2 & Leaves & [95] \\
\hline (24R)-24-Ethyl-cholest-5-en-3 $\beta$-ol-7-one (\%) & 1.6 & Leaves & [95] \\
\hline Pinoresinol & - & Leaves & [95] \\
\hline 3-(4-hydroxy-3-methoxy)-phenyl-1,2-propandiol & - & Leaves & [95] \\
\hline 3-(4-hydroxy-3-methoxy-phenyl)-1,2,3-propantriol & - & Leaves & [95] \\
\hline 2-(3,4-dihydroxy)-phenyl-ethyl- $\beta$-D-glucopyranoside & - & Leaves & [95] \\
\hline Isoswertiajaponin & - & Leaves & [95] \\
\hline Isoswertisin & - & Leaves & [95] \\
\hline 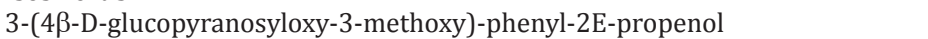 & - & Leaves & [95] \\
\hline 3-(4-hydroxy-3-methoxy)-phenyl-2E-propenyl-1 $\beta$-D-glucopyranoside & - & Leaves & [95] \\
\hline 3-(4ß-D-glucopyranosyloxy-3,5-dimethoxy)-phenyl-2E-propenol & - & Leaves & [95] \\
\hline $\begin{array}{l}\text { 1-(4-hydroxy-3-methoxy)-phenyl-2-[4-(2,3-dihydroxypropyl)-2-methoxy] } \\
\text {-phenoxy-1,3-propandiol }\end{array}$ & - & Leaves & [95] \\
\hline 6-(o-hydrobenzylamino)-9- $\beta$-D-ribofuranosylpurine & - & Fruits & [98] \\
\hline 6-(o-hydrobenzylamino)-2-methylthio-9- $\beta$-D-glucofuranosylpurine & - & Fruits & [97] \\
\hline Allyl decanoate (\%) & 0.02 & Leaves & [90] \\
\hline 2-Azido-2-methylpentane (\%) & 0.01 & Leaves & [90] \\
\hline Aziridine, 2,2-dimethyl (\%) & 0.2 & Leaves & [90] \\
\hline Benzene, 1,2,3-trimethyl (\%) & 0.003 & Leaves & [90] \\
\hline Docosanoic acid, methyl ester (\%) & 0.01 & Leaves & [90] \\
\hline E-1,8-decadiene (\%) & 0.1 & Leaves & [90] \\
\hline 11-Dodecen-1-al (\%) & 0.02 & Leaves & [90] \\
\hline 1-Dodecyne (\%) & 0.1 & Leaves & [90] \\
\hline Undecane $(\%)$ & 0.006 & Leaves & [90] \\
\hline $2(3 \mathrm{H})$-Furanone, dihydro-4-methyl (\%) & 0.1 & Leaves & [90] \\
\hline 9-Octadecenoic acid (Z) (\%) & 0.1 & Leaves & [90] \\
\hline 17-Octadecynoic acid (\%) & 0.3 & Leaves & [90] \\
\hline 9,12 -Octadecadienal $(\%)$ & 0.3 & Leaves & [90] \\
\hline 9,12-Octadecadienoyl chloride, (Z, Z) & 0.2 & Leaves & [90] \\
\hline 2-Oxetanone, 3,3-dimethyl (\%) & 0.3 & Leaves & [90] \\
\hline Phenol, 2-methyl-5-(1-methylethyl) (\%) & 0.004 & Leaves & [90] \\
\hline Phenol, 4,4'-(1-methylethylidene) bis (\%) & 0.003 & Leaves & [90] \\
\hline Phenol, 5-methyl-2-(1-methylethyl) (\%) & 0.008 & Leaves & [90] \\
\hline Stigmastan-3,5-diene (\%) & 0.1 & Leaves & [90] \\
\hline Stigmastan-6,22-dien, 3,5-dedihydro (\%) & 0.06 & Leaves & [90] \\
\hline d1- $\alpha$-Tocopherol (\%) & 0.004 & Leaves & {$[90]$} \\
\hline Campesterol & - & Leaves & [101] \\
\hline$\beta$-Sitosterol & - & Leaves & {$[101]$} \\
\hline Stigmasterol & - & Leaves & {$[101]$} \\
\hline
\end{tabular}


amphotericin B as a positive control. The extracts exhibited activities with MIC and minimum fungicidal concentration (MFC) values ranging from $1.6 \mathrm{mg} / \mathrm{ml}$ to $>12.5 \mathrm{mg} / \mathrm{ml}$ which was comparable to MIC and MFC values of $0.008 \mathrm{mg} / \mathrm{ml}$ and $0.01 \mathrm{mg} / \mathrm{ml}$, respectively, which were exhibited by the controls [54].

\section{Antithrombotic and anticoagulant activities}

Kee et al. [104] evaluated antithrombotic and/or anticoagulant activities of methanol and aqueous leaf extracts of $Z$. aethiopica using the thrombin and clotting time (thrombin induced and $\mathrm{CaCl}_{2}$ induced) assays. The extract displayed anticoagulant activities with half maximal inhibitory concentration ( $\mathrm{IC}_{50}$ ) value of $3.1 \mathrm{mg} / \mathrm{ml}$ [104]

\section{Antioxidant activities}

Li et al. [105] evaluated the antioxidant activities of the flower extracts of $Z$. aethiopica using the ferric-reducing antioxidant power (FRAP) and Trolox equivalent antioxidant capacity (TEAC) assays. The extracts exhibited FRAP value of $22.1 \pm 0.6 \mu \mathrm{mol} \mathrm{Fe(II)/g} \mathrm{wet}$ weight while the TEAC value was $9.2 \pm 0.4 \mu \mathrm{mol}$ Trolox/g wet weight and the total phenolic content was $3.1 \pm 0.01 \mathrm{mg} \mathrm{GAE} / \mathrm{g}$ wet weight. The main phenolic compounds were epicatechin (37.9 mg/100 g), gallic acid (30.8 mg/100 g), and protocatechuic acid (42.6 mg/100 g). Li et al. [105] also evaluated the insoluble-bound components of the residue using the $\mathrm{NaOH}$ hydrolysis and FRAP value was $0.7 \pm 0.08 \mu \mathrm{mol}$ $\mathrm{Fe}(\mathrm{II}) / \mathrm{g}$ wet weight, TEAC $(0.3 \pm 0.04 \mu \mathrm{mol}$ Trolox/g wet weight $)$, and the total phenolic content was $0.3 \pm 0.01 \mathrm{mg} \mathrm{GAE} / \mathrm{g}$ wet weight.

\section{Antihistaminic activities}

Motlhatlego [54] evaluated the antihistaminic activities of the ethanolic leaf, rhizome, root, and stem extracts of Z. aethiopica using antihistamine assay. The leaf extracts exhibited histamine receptor binding of $88 \%$ at both concentrations of $400 \mu \mathrm{g} / \mathrm{ml}$ and $800 \mu \mathrm{g} / \mathrm{ml}$ [54].

\section{Antialgal activities}

Greca et al. [95] evaluated antialgal activities of ethyl acetate and methanol leaf extracts of $Z$. aethiopica against Selenastrum capricornutum using a paper disk assay. The extracts showed inhibitory effects. Greca et al. [95] assayed compounds pinoresinol, 3-(4-hydroxy-3-methoxy)-phenyl-1,2-propandiol, 3-(4-hydroxy3-methoxy-phenyl)-1,2,3-propantriol, 2-(3,4-dihydroxy)-phenylethyl- $\beta$-D-glucopyranoside, isoswertiajaponin, isoswertisin, 3-(4 $\beta$-D-glu copyranosyloxy-3-methoxy)-phenyl-2E-propenol, 3-(4-hydroxy-3-methoxy)-phenyl-2E-propenyl-1 $\beta$-D-glucopyranoside, 3 - ( $4 \beta$ - D - glu co py ran o syloxy - 3, 5 - di me th oxy) - phe nyl2E-propenol, and 3-(4-hydroxy-3,5-dimethoxy)-phenyl-2E-propenyl$1 \beta$-D-glucopyranoside at concentrations from $10^{-3} \mathrm{M}$ to $10^{-5} \mathrm{M}$ in broth, while compounds 1-(4-hydroxy-3-methoxy)-phenyl-2-[4(1,2,3-tri-hydroxypropyl)-2-methoxy]-phenoxy-1,3-propandiol and 1-(4-hydroxy-3-methoxy)-phenyl-2-[4-(2,3-dihydroxypropyl)2-methoxy]-phenoxy-1,3-propandiol tested by paper disk assays. Only compounds 1-(4-hydroxy-3-methoxy)-phenyl-2-[4-(1,2,3tri-hydroxypropyl)-2-methoxy]-phenoxy-1,3-propandiol and 1-(4-hydroxy-3-methoxy)-phenyl-2-[4-(2,3-dihydroxypropyl)-2methoxy]-phenoxy-1,3-propandiol $(0.1 \mu \mathrm{mol})$ gave $15 \mathrm{~mm}-23 \mathrm{~mm}$ diameters of inhibition which was similar to activities exhibited by the control algicide $\mathrm{CuSO}_{4}$. The compounds pinoresinol, 3-(4-hydroxy3-methoxy)-phenyl-1,2-propandiol, and 3-(4-hydroxy-3-methoxyphenyl)-1,2,3-propantriol showed weak activities causing $40 \%$ inhibition at $10^{-4} \mathrm{M}[95]$.

\section{CONCLUSION}

Z. aethiopica is a well-known medicinal plant species in Southern Africa where the species is indigenous. The species has been introduced in several countries and is now regarded an important component of indigenous pharmacopoeia in Brazil, India, Malawi, Mexico, and Tanzania where the species is naturalized. The historical traditional usage of Z. aethiopica as herbal medicine in Southern Africa and other regions where the species is naturalized calls for detailed phytochemical and pharmacological studies aimed at correlating its documented ethnomedicinal uses with the phytochemical and pharmacological properties of the species. There is a need for clinical and toxicological evaluations since Z. aethiopica contains potentially toxic compounds. Therefore, future research should focus on identification of toxic compounds, the possible side effects caused by taking Z. aethiopica as herbal medicine, and mechanisms of how potential toxic components of the species can be managed when the species is used as herbal medicine.

\section{ACKNOWLEDGMENTS}

I would like to express my gratitude to the National Research Foundation, South Africa, and Govan Mbeki Research and Development Centre, University of Fort Hare, for financial support to conduct this study.

\section{AUTHORS' CONTRIBUTIONS}

The author declares that this work was done by the author named in this article.

\section{CONFLICTS OF INTEREST}

The author declares that he has no conflicts of interest.

\section{REFERENCES}

1. Snijder RC, Lindhout P, Tuyl JM. Genetic control of resistance to soft rot caused by Erwinia carotovora subsp. carotovora in Zantedeschia spp. (Araceae), section Aestivae. Euphytica 2004;136:319-25.

2. Wright PJ, Triggs CM, Burge GK. Control of bacterial soft root of calla (Zantedeschia spp.) by pathogen exclusion, elimination and removal. N Z J Crop HortSci 2005;33:117-23.

3. Ni L, Li X, Custers JB, Zhang K, Zhang L. Response of arum lily calli to culture filtrate of Pectobacterium carotovorum subsp. carotorum. Afr J Biotechnol 2009;8:5362-6.

4. Rizzo D, Lazzereschi S, Nesi B, Stefani L, Paoli M, Della BM, et al. Zantedeschia aethiopica L. serious damages by INSV Colture Prot 2012;41:62-6.

5. Sandoval-Herazo LC, Alvarado-Lassman A, Marín-Muñiz JL, Méndez-Contreras JM, Zamora-Castro SA. Effects of the use of ornamental plants and different substrates in the removal of wastewater pollutants through microcosms of constructed wetlands. Sustainability 2018;10:1594.

6. Sandoval L, Zamora-Castro SA, Vidal-ÁlvarezM, Marín-MuñizJL. Role of wetland plants and use of ornamental flowering plants in constructed wetlands for wastewater treatment: A review. Appl Sci 2019;9:685.

7. Halligan EA, Brooking IR, Funnell KA, Catley JL. Vegetative and floral shoot development of Zantedeschia black magic. Sci Hortic 2004;99:55-65.

8. Wei ZZ, Luo LB, Zhang HL, Xiong M, Wang X, Zhou D, et al. Identification and characterization of 43 novel polymorphic EST-SSR markers for arum lily, Zantedeschia aethiopica (Araceae). Am J Bot 2012;99:e493-7.

9. Standley PC, Steyermark JA. Flora of Guatemala. Fieldiana Bot 1958;24:304-63.

10. Plowman T. Folk uses of new world aroids. Econ Bot 1969:23:97-122

11. Lorenzi H, de Souza HM. Plantasornamentais no Brasil: Arbustivas, Herbáceas e Trepadeiras. São Paulo: Plantarum, Nova Odessa; 1995.

12. Reinten EY, Coetzee JH, Van Wyk BE. The potential of South African indigenous plants for the international cut flower trade. S Afr J Bot 2011;77:934-46

13. Van Wyk BE, Van Oudtshoorn B, Gericke N. Medicinal plants of South Africa. Pretoria: Briza Publications; 2013.

14. Jackson WP. The Cape white arum lily, Zantedeschia aethiopica. Veld F1 1986;72:44-5

15. Van Wyk BE, Gericke N. Peoples' Plants: A Guide to Useful Plants of Southern Africa. Pretoria: Briza Publications; 2007.

16. Guillarmod A. A contribution towards the economic botany of Basutoland. Bot Not 1966;119:209-11

17. Guillarmod AJ. Flora of Lesotho. Lehre: Cramer; 1971.

18. Rose EF, Guillarmod AJ. Plants gathered as foodstuffs by the Transkeian peoples. S Afr Med J 1974;48:1688-90.

19. Fox FW, Young ME. Food from the Veld: Edible Wild Plants of Southern Africa. Johannesburg: Delta Books; 1982.

20. Schmitz MO. Wild Flowers of Lesotho. Roma: ESSA; 1982. 
21. Peters CR, O'Brien EM, Drummond RB. Edible wild plants of SubSaharan Africa. London, Kew: Royal Botanic Gardens; 1992.

22. Soper R. The Terrace Builders of Nyanga. Harare: Weaver Press; 2006.

23. Moffett RO. Sesotho Plant and Animal Names and Plants used by the Basotho. Stellenbosch: Sun Press; 2010.

24. Dweba P, Mearns MA. Conserving indigenous knowledge as the key to the current and future use of traditional vegetables. Int J Inf Manag 2011;31:564-71.

25. Jaca TP, Kambizi L. Antibacterial properties of some wild leafy vegetables of the Eastern Cape province, South Africa. J Med Plants Res 2011;5:2624-8.

26. Ntuli NR, Zobolo AM, Siebert SJ, Madakadze RM. Traditional vegetables of Northern KwaZulu-Natal, South Africa: Has indigenous knowledge expanded the menu? Afr J Agric Res 2012;7:6027-34.

27. Van Wyk BE, Van Heerden FR, Van Oudtshoorn B. Poisonous Plants of South Africa. Pretoria: Briza Publications; 2002.

28. Slaughter RJ, Beasley DM, Lambie BS, Wilkins GT, Schep LJ. Poisonous plants in New Zealand: A review of those that are most commonly enquired about to the national poisons centre. N Z Med J 2012;125:87-118.

29. Botha CJ, Penrith ML. Poisonous plants of veterinary and human importance in Southern Africa. J Ethnopharmacol 2008;119:549-58.

30. Wink M, Van Wyk BE. Mind-altering and Poisonous Plants of the World. Pretoria: Briza Publications; 2008.

31. Ndhlala AR, Ncube B, Okem A, Mulaudzi RB, Van Staden J. Toxicology of some important medicinal plants in southern Africa. Food Chem Toxicol 2013;62:609-21.

32. Moeng TE. An Investigation into the Trade of Medicinal Plants by Muthi Shops and Street Vendors in the Limpopo Province, South Africa. MSc Dissertation. Sovenga: University of Limpopo; 2010.

33. Rasethe MT, Semenya SS, Maroyi A. Medicinal plants traded in informal herbal medicine markets of the Limpopo province, South Africa. Evid Based Complement Altern Med 2019;2019:2609532.

34. Leitão FS, da Fonseca-Kruel VS, Silva IM, Reinert F. Urban ethnobotany in Petropolis and Nova Friburgo (Rio de Janeiro, Brazil). Rev Bras Farmacogn 2009; 19:333-42.

35. Leitão F, Leitão SG, da Fonseca-Kruel VS, Silva IM, Martins K. Medicinal plants traded in the open-air markets in the State of Rio de Janeiro, Brazil: An overview on their botanical diversity and toxicological potential. Rev Bras Farmacogn 2014;24:225-47.

36. Letty C. The genus Zantedeschia. Bothalia 1973;11:5-26

37. Singh Y, Van Wyk AE, Baijnath H. Floral biology of Zantedeschia aethiopica (L.) Spreng. (Araceae). S Afr J Bot 1996;62:146-50.

38. Manning JC, Goldblatt P. Plants of the Greater Cape Floristic Region 1: The Core Cape Flora. Cape Town: Strelitzia 29, South African National Biodiversity Institute; 2012.

39. Snijman DA. Plants of the Greater Cape Floristic Region: The Extra Cape Flora. Vol. 2. Pretoria: Strelitzia 30, South African National Biodiversity Institute; 2013.

40. Arnold TH, De Wet BC. Plants of Southern Africa: Names and Distribution. Pretoria: Memoirs of the Botanical Survey of South Africa, National Botanical Institute; 1993.

41. Germishuizen G, Meyer NL. Plants of Southern Africa: An Annotated Checklist. Pretoria: Strelitzia 14, National Botanical Institute; 2003.

42. El Mokni R, El Aouni MH. Zantedeschia aethiopica (Araceae) a new species naturalized in the Northwest of Tunisia. Flora Mediterr 2012;22:191-6

43. Parsons WT, Cuthbertson EG. Noxious Weeds of Australia. Melbourne: CSIRO Publishing; 1992.

44. Scott JK, Delfosse ES. Southern African plants naturalized in Australia: A review of weed status and biological control potential. Plant Prot Q 1992; 7:70-80

45. Hansen A, Sunding P. Flora of Macaronesia: Checklist of vascular plants. Sommerfeltia 1993;17:1-295

46. Scott JK, Neser S. Prospects for the Biological Control of the Environmental Weed, Zantedeschia aethiopica (Arum lily). In: Shepherd RC, editor. Proceedings of the $11^{\text {th }}$ Australian Weeds Conference. Melbourne, Australia, 30 September, 3 October, 1996. Victoria: Weed Science Society of Victoria; 1996. p. 413-6.

47. Tassin J, Riviere JN. Invasive plants on Réunion. Courrier Nat 1999; 177:28-33

48. Khare CP. Indian Medicinal Plants: An Illustrated Dictionary. Berlin: Springer-Verlag; 2007.

49. Celesti-Grapow L, Alessandrini A, Arrigoni PV, Assini S, Banfi $\mathrm{E}$, Barni E, et al. Non-native flora of Italy: Species distribution and threats. Plant Biosyst 2010;144:12-28.

50. Weber E. Invasive Plant Species of the World: A Reference
Guide to Environmental Weeds. Wallingford: CAB International Publishing; 2003.

51. Quattrocchi FL. CRC World Dictionary of Plant Names, Common Names, Scientific Names, Eponyms, Synonyms and Etymology. London: CRC Press; 2000.

52. Aubrey A. Zantedeschia aethiopica (L.) Spreng; 2001. Available from: http://www.pza.sanbi.org/zantedeschia-aethiopica. [Last accessed on 2019 Apr 24]

53. Aston Philander L. An ethnobotany of western cape Rasta bush medicine. J Ethnopharmacol 2011;138:578-94.

54. Motlhatlego KE. Evaluation of Plants used in African Traditional Medicine for Asthma and Related Conditions. MSc Dissertation. Pietermaritzburg: University of KwaZulu-Natal; 2014.

55. Szuman KM, Lall N. Aquatic Plants of South Africa for Pharmaceutical and Cosmeceutical Usage. Pretoria: Water Research Commission; 2016.

56. Semenya SS, Maroyi A. Plants used by Bapedi traditional healers to treat asthma and related symptoms in Limpopo province, South Africa. Evid Based Complement Altern Med 2018;2018:2183705.

57. Hulley IM, Van Wyk BE. Quantitative medicinal ethnobotany of Kannaland (Western Little Karoo, South Africa): Non-homogeneity amongst villages. S Afr J Bot 2019;122:225-65

58. Watt JM, Breyer-Brandwijk MG. The Medicinal and Poisonous Plants of Southern and Eastern Africa. Edinburgh: E and S Livingstone; 1962.

59. Morris B. Spring flowers of Brachystegia woodland: Arums and gingers. Soc Malawi J 1987;40:39-48.

60. Morris B. Wildlife and Landscapes in Malawi: Selected Essays on Natural History. Victoria: Trafford Publishing; 2008.

61. Long C. Swaziland's Flora: siSwati Names and Uses. Mbambane, Swaziland: Swaziland National Trust Commission; 2005. Available from: http://www.sntc.org.sz/index.asp. [Last accessed on 2019 Apr 14].

62. Moteetee A, Van Wyk BE. The concept of musa-pelo and the medicinal use of shrubby legumes (Fabaceae) in Lesotho. Bothalia 2007;37:75-7.

63. Nielsen TR, Kuete V, Jäger AK, Meyer JJ, Lall N. Antimicrobial activity of selected South African medicinal plants. BMC Complement Altern Med 2012;12:74.

64. Mabona U. Antimicrobial Activity of Southern African Medicinal Plants with Dermatological Relevance. MSc Dissertation. Johannesburg: University of the Witwatersrand; 2013

65. Mabona U, Van Vuuren SF. Southern African medicinal plants used to treat skin diseases. S Afr J Bot 2013;87:175-93.

66. Moteetee A. A review of plants used for magic by Basotho people in comparison with other cultural groups in Southern Africa. Indian J Tradit Knowl 2017;16:229-34

67. Bodiba D, Szuman KM, Lall N. The role of medicinal plants in oral care. In: Lall N, editor. Medicinal Plants for Holistic Health and WellBeing. London: Academic Press; 2018. p. 200-12

68. Moteetee A, Moffett RO, Seleteng-Kose L. A review of the ethnobotany of the Basotho of Lesotho and the Free State province of South Africa (South Sotho). S Afr J Bot 2019;122:21-56

69. Schultes RE. Economic Aspects of the Flora of North Eastern Oaxaca, Mexico. PhD Thesis. Cambridge, Massachusetts: Harvard University; 1941

70. Grierson DS, Afolayan AJ. An ethnobotanical study of plants used for the treatment of wounds in the Eastern Cape, South Africa. J Ethnopharmacol 1999;67:327-32.

71. Afolayan AJ, Grierson DS, Mbeng WO. Ethnobotanical survey of medicinal plants used in the management of skin disorders among the Xhosa communities of the Amathole district, Eastern Cape, South Africa. J Ethnopharmacol 2014;153:220-32.

72. Adebayo SA, Masoko P. Therapeutic uses of plant species for inflammation-related conditions in Limpopo province of South Africa: A mini-review and current perspectives. Int J Pharmacogn Phytother Res 2017;1:2-8.

73. Choi CW, Song SB, Oh JS, Kim YH. Antiproliferation effects of selected Tanzania plants. Afr J Tradit Complement Altern Med 2015;12:96-102.

74. Lall N, Kishore N. Are plants used for skin care in South Africa fully explored? J Ethnopharmacol 2014;153:61-84

75. Fernandes L, Van Rensburg CEJ, Hoosen AA, Steenkamp V. In vitro activity of medicinal plants of the Venda region, South Africa, against Trichomonas vaginalis. S Afr J Epidemiol Inf 2008;23:26-8.

76. Arnold HJ, Gulumian M. Pharmacopoeia of traditional medicine in Venda. J Ethnopharmacol 1984;12:35-74.

77. Steenkamp V. Traditional herbal remedies used by South African women for gynaecological complaints. J Ethnopharmacol 2003;86:97-108.

78. Abdillahi HS, Van Staden J. Application of medicinal plants in maternal healthcare and infertility: A South African perspective. Planta Med 2013;79:591-9. 
79. Manikandan PN. Ethno medico botanical studies of Badaga population in the Nilgiri district of Tamil Nadu, South India. Anc Sci Life 2008;27:50-9.

80. Mir AH, Upadhaya K, Choudhury H. Diversity of endemic and threatened ethnomedicinal plant species in Meghalaya, North East India. Int Res J Environ Sci 2014;3:64-78.

81. van Wyk BE. A review of Khoi-San and cape Dutch medical ethnobotany. J Ethnopharmacol 2008;119:331-41

82. Philander LE, Makunga NP, Platten SJ. Local medicinal plant knowledge in South Africa preserved by apartheid. Hum Ecol 2011;39:203-16.

83. Mabona U, Viljoen A, Shikanga E, Marston A, Van Vuuren S. Antimicrobial activity of Southern African medicinal plants with dermatological relevance: From an ethnopharmacological screening approach, to combination studies and the isolation of a bioactive compound. J Ethnopharmacol 2013;148:45-55.

84. Dyubeni L, Buwa LV. An ethnobotanical study of plants used for the treatment of ear, nose and throat (ENT) infections in Nkonkobe Municipality, South Africa. J Med Plants Res 2012;6:2721-6.

85. Buwa-Komoreng LV, Mayekiso B, Mhinana Z, Adeniran AL. An ethnobotanical and ethnomedicinal survey of traditionally used medicinal plants in Seymour, South Africa: An attempt toward digitization and preservation of ethnic knowledge. Pharmacogn Mag 2019; $15: 115-23$.

86. Albertyn R, Berg A, Numanoglu A, Rode H. Traditional burn care in Sub-Saharan Africa: A long history with wide acceptance. Burns 2015;41:203-11.

87. Maroyi A. Diversity of use and local knowledge of wild and cultivated plants in the Eastern Cape province, South Africa. J Ethnobiol Ethnomed 2017;13:43

88. Masika PJ, Afolayan AJ. An ethnobotanical study of plants used for the treatment of livestock diseases in the Eastern Cape Province, South Africa. Pharm Biol 2003;41:16-21.

89. Carneiro DN, Coelho LL, Paiva PD, Almeida EF, Carneiro LF. Evaluation of macronutrient demand in calla lily (Zantedeschia aethiopica). Aust J Crop Sci 2015;9:761-6.

90. Pelo SP. Phytochemical Analysis and Antibacterial Properties of Zantedeschia aethiopica. MSc Dissertation. Johannesburg: University of Johannesburg; 2016

91. Food and Agriculture Organization. Codex Alimentarious Commission. Contaminants, Joint FAO/WHO Food Standards Program. Geneva: Codex Alimentarious; 1984.

92. Maroyi A. Phytochemical and ethnopharmacological review of Heteropyxis natalensis. Asian J Pharm Clin Res 2019;12:8-15.
93. Maroyi A. Lannea schimperi: Review of its botany, medicinal uses, phytochemistry and biological activities. Asian J Pharm Clin Res 2019;12:31-6.

94. Willaman JJ, Schubert BG. Alkaloid-bearing Plants and their Contained Alkaloids. Washington DC: US Department of Agriculture; 1961.

95. Greca MD, Ferrara M, Fiorentino A, Monaco P, Previtera L. Antialgal compounds from Zantedeschia aethiopica. Phytochemistry 1998;49:1299-304

96. Pratush A, Dogra S, Gupta A. Antimicrobial and phytochemical screening of rhizome extracts of some native medicinal plant of Himachal Pradesh (India). Appl Biol Res 2013;15:1-5.

97. Chaves das Neves HJ, Pais MS. Identification of a spathe regreening factor in Zantedeschia aethiopica. Biochem Biophys Res Commun 1980;95:1387-92.

98. Chaves das Neves HJ, Pais MS. A new cytokinin from the fruits of Zantedeschia aethiopica. Tetrahedron Lett 1980;21:4387-90.

99. Melo N, Tavares RM, Morais F, Barroso JG, Pais MS. Lipid composition of thylakoid membranes from leaves and regreened spathes of Zantedeschia aethiopica. Phytochemistry 1995;40:1367-71.

100. Tavares RM, Morais F, Melo N, Pais MS. Thylakoid membrane reorganization during Zantedeschia aethiopicas pathe regreening: Consequence of the absence of $\Delta 3$-trans-hexadecenoic acid in photochemical activity. Phytochemistry 1998;47:979-84.

101. Liu ZH, Yang ZX. Isolation and identification of phytosterol from Zantedeshia aethiopica. China Pharm 2007;10:978-9.

102. Motsei ML. Screening of Traditionally used South African Medicinal Plants against Candida albicans. MSc Dissertation. Pietermaritzburg: University of KwaZulu-Natal; 2013

103. Motsei ML, Lindsey KL, van Staden J, Jäger AK. Screening of traditionally used South African plants for antifungal activity against Candida albicans. J Ethnopharmacol 2003;86:235-41.

104. Kee NL, Mnonopi N, Davids H, Naudé RJ, Frost CL. Antithrombotic/ anticoagulant and anticancer activities of selected medicinal plants from South Africa. Afr J Biotechnol 2008;7:217-23.

105. Li AN, Li S, Li HB, Xu DP, Xu XR, Chen F. Total phenolic contents and antioxidant capacities of 51 edible and wild flowers. J Funct Foods 2014;6:319-30.

106. de Almeida RG, Silva ON, Cândido ES, Moreira JS, Jojoa DE,Gomes DG, et al. Screening and isolation of antibacterial proteinaceous compounds from flower tissues: Alternatives for treatment of healthcare-associated infections. Tang 2014;4:e5 